\title{
6 Feminism, global inequality, and the 1975 Mexico city conference
}

\author{
Aoife O'Donoghue and Adam Rowe
}

\section{Introduction}

The 1975 Women's Conference was significant, both as a single event but also in terms of its legacy across law, politics, and women's global campaigning within and outside of the UN structure. ${ }^{1}$ While law was not created at the Conference what was established was momentum, contestation, and a demonstration that previous attempts to tackle women's issues, including via treaty writing, by a male dominated global diplomatic core, including the UN, were insufficient.

While women have always been present and active in the modern era of global campaigning and law-making, they were excluded, informally and formally from the official law and policy making table. But what is more, women's issues have been dominated by voices from the Global North. Global South women were, and are, excluded far more than their Western counterparts. The Mexico Conference brought this inequality and the tensions stemming from it, directly into the spotlight by virtue of the fact that it took place not only in the context of the Cold War but also at a moment when a surge of states from the Global South were seeking to reorient law, through the New International Economic Order, away from its imperial and colonial origins.

In the commentaries and histories regarding both the 1975 Conference, and those held since, the focus is often on the particular character of the disagreements and controversies. Debate and arguments are commonplace at all thematic global conferences, be that at the UN or other global bodies, such as the WTO. The Battle of Seattle, at the 1999 WTO Ministerial Conference, is a recent example of heated debate both inside and outside of a global conference on law and policy. In the narratives presented on the 1975 Conference, however, conflict amongst women is presented as fundamental and distinctive to women's events. That women should not agree on the best path towards equality, that their lived experiences are different, and that conflict may arise is seen as substantive rather than typical of international questions that deal with half the world's population. While it is accepted that theorists of positivism, of natural law or communism disagree, sometimes fundamentally, feminism's contestations are presented as a fundamental flaw born of emotionalism rather than reasoned disagreement. This is not to ignore the debates. The voice of Global South women demanding to be heard is critical as is the confrontation of Western feminist privilege, both issues are core to debates on legal reform. But a narrative that presents women's 
conferences as essentially antagonistic because feminist campaigning is an exceptional argumentative space needs to be forestalled. ${ }^{2}$

In sum, then, this chapter examines the legal and political legacy of the 1975 Conference in several contexts. First, we can approach the Conference through the historical struggle of feminist activists to achieve official participation in the legal and policy forums addressing women's issues. But more than that, the Conference can be used to explore the internal relations and tensions within feminism itself. In this vein, the ongoing challenge to Global North feminists to cede space and end attempts at articulating and representing all women's lived experiences, the role of the New International Economic Order and international economic law within that context of the Global South to change global legal governance and the overarching impact of the Cold War, will be central themes of analysis.

\section{History of international conferences on women}

Since the advent of the modern international conference, women have played significant roles. Initially excluded from inter-state conferences, women organized their own parallel events. They were amongst the first non-state campaign groups to employ this tactic and, at times, succeeded in gaining legal change. ${ }^{3}$ Moreover, women were also amongst the leaders of the anti-slavery, peace, and labour movements that arose in the 19th century and which continue to be essential debates within contemporary international legal discourse. Absent formal roles in inter-state conferences women as facilitators in salons and social events were so critical that the UK Foreign Office, into the post-World War II era, opposed diplomatic wives holding other careers so that they could focus on these social events. ${ }^{4}$ Inevitably during an era of imperialism, these alliances and groups were dominated by white western women, a legacy that remains partly intact, particularly in formal institutions. Nonetheless women from beyond the Global North broke through formal barriers - a development that often led to significant changes which produced substantial shifts in international policy and law.

Global women's organizations of the late 19th and early 20th centuries were able to realize substantive legal change - change, moreover, that occurred contemporaneously with the evolution of modern international law. As was alluded to above, women were excluded from formal settings. To overcome such obstacles, they had to devise innovate strategies to effect legal change. In doing so, these first organizations were instrumental in setting the template for lobbying for change by NGOs outside the 20th century global institutions.

Outside of their demonstration of the potential effectiveness of NGOs in advancing legal reform, the early feminist organizations recognized the need for global coalitions. The Inter-Allied Suffrage Conference, The International Women's Congress for Peace and Freedom, and the Women's International League for Peace and Freedom emerged initially as national organizations but realized that issues, such as peace and trafficking of women, by necessity required an international response to effect legal change. ${ }^{5}$ The Second International Congress 
of Women, held in parallel to the Versailles Peace Conference, is an important example of the potency of women's coalitions. They campaigned at Versailles to ensure women were eligible to work at the League of Nations and succeeded in inserting Article 7 into the Covenant of the League of Nations. ${ }^{6}$

Beyond NGO activity, several women, such as Rachel Crowdy, managed to gain roles within the League influencing work on the Advisory Committee on Traffic in Women and Children and the drafting of the Convention on the Traffic of Women and Children and the Convention on the Suppression of and Circulation of Obscene Publication. ${ }^{7}$ But within the League, women were often limited to issues that were defined as concerning them - health, childbirth, nutrition, education. ${ }^{8}$ What constituted women's concerns was judged by men. How women could influence these and other areas, as well as which women were able to gain influence, were all curtailed. When attempts were made within the League to examine the status of women, McKinnon Wood, an official in the Legal Department, wrote that he and the Secretary General agreed that "the question of the political and civil rights of women is unsuitable for international action" and that any movement towards raising issues were mere agitators such as Alice Paul' a US feminist. ${ }^{9}$

While some in the League made valiant efforts to advance women's issues, large populations of women, many of whom still lived under colonialism, were entirely excluded from the debate. Their specific issues were either not raised or defined by others. This was despite the fact that Latin American women often led campaigns to address issues of concern to women, demonstrating that critical Global South leadership is possible and necessary to address women's issues beyond a Euro-American gaze but also that women had to make these spaces for themselves. ${ }^{10}$ Women achieved some success in the League's successor, the UN. Following the work of women such as Bertha Lutz, women were eligible for roles in the UN Secretariat and the leadership of women from Latin America was essential in ensuring that gender was on the UN's agenda. ${ }^{11}$ This included the creation of the Commission on the Status of Women in 1946 led by Bodil Begtrup, the main avenue for feminist action within the UN structure. $^{12}$

While Euro-American feminist organizations often dominated, after 1945, these NGO organizations were frequently divided between the West and Communist states. Additionally, the question of decolonization served to create tensions between Global North and South states. Rather than recognize that the Global South formed a distinct group with unique interests, their perspective has often been suppressed into the Cold War divide. The exclusion of women from the League of Nations and the UN, the defining of topics of interest to women, the exclusion of women from the Global South and decolonization all formed part of the legacies raised in Mexico. ${ }^{13}$ But also, part of this legacy was the form and structure of these global conferences. Women had built networks of organizations and campaigns, had created and developed the processes of parallel conferences as a way to affect legal change when excluded from fora, but were also facing their own processes of exclusion and privilege, all of which would become apparent in Mexico City. 


\section{International women's year}

The post-colonial context, including the legacy of the Bandung Conference and the debates on the New International Economic Order, the Non-Aligned Movement, and the Group of 77 meant that the Global South, was an increasingly significant voice within international conferences. ${ }^{14}$ The Cold War, beyond women's rights, had made the Global South a site of confrontation. The tensions between the Western dominated International Council of Women and the socialist and anti-colonial basis of the Women's International Democratic Federation typified these tensions - albeit cooperation and progress on women's issues were still consistently made amongst these organizations. ${ }^{15} \mathrm{By}$ the time of the Mexico Conference, the domination of particular NGOs and their relationships with the UN structures was also a source of friction especially for those that did not have easy access to lobbying possibilities.

The Mexico Conference was the first inter-governmental global conference to focus on women, but the initial proposal was centred on a women's year. The first thematic year was in 1959/60 and focussed upon the human rights issues of refuges (such designations would become a feature of UN activity). ${ }^{16}$ This initiative, as well as for the 1975 Conference, came to the UN Commission on the Status of Women (CSW) from NGOs. The CSW debates reflected both the vast array of issues that needed to be discussed, the differences amongst the NGOs, but also what types of events were likely to advance women's human rights and what topics should be included. The CSW ultimately declared its decision to "devote this year to intensified action to promote equality between men and women and to increase women's contribution to national and international development."17

The General Assembly Resolution, accepting the CSW proposal, focussed International Women's Year on three issues: (a) To promote equality between men and women; (b) To ensure the full integration of women in the total development effort, especially by emphasizing women's responsibility and important role in economic, social, and cultural development at the national, regional, and international levels, particularly during the Second United Nations Development Decade; (c) To recognize the importance of women's increasing contribution to the development of friendly relations and co-operation amongst States and to the strengthening of world peace. ${ }^{18}$

Outside of these three core points of focus, a partial aim was to highlight the lack of progress on legal reform, the continued domination of debate on liberal rights and of the Global North states in setting the terms of debate. ${ }^{19}$

A conference on women had been debated at the CSW since 1947. The specific proposal for the 1975 event came from Australian Julie Dahlitz and was coupled with eventual Australian government support though Elizabeth Reid, the first advisor to the Australian Prime Minister on women's issues. ${ }^{20}$ The official proposal was put before the CSW by Patricia Hutar, a US delegate. ${ }^{21}$ The proposal was not unanimously supported. Soviet bloc states argued it would be, like other themed conferences, a gimmick, due both to their expense - for the UN and for delegates, and their general lack of substantive outcome. They suggested that the General Assembly should include debate on IWY as a special agenda item, 
a process that had been used to discuss terrorism, as this would have a greater impact. $^{22}$

Ultimately the resolution to hold a conference was supported by CSW and ECOSOC and adopted by the General Assembly. ${ }^{23}$ Tensions on interpreting the themes, funding, location, and the content of what was to be debated immediately became sources of tension. This is perhaps unsurprising given the hitherto lack of focus on women at a major global event. Amongst these tensions, however, the question of which state would host became particularly serious. ${ }^{24}$ Mexico City was the eventual location after Colombia withdrew their offer to host.

Mexico's hosting of the Conference was significant for a number of reasons. Most immediately, the decision to ratify its hosting came in the same session as Mexico's sponsorship of the Charter on the Economic Rights and Duties of States. The Charter was a key aim of the New International Economic Order. Given this context, Mexico's selection placed the Global South's international legal ambitions directly into the foreground of the Conference. ${ }^{25}$ However, Mexican President Echeverría's poor human rights record resulted in Mexican feminists being unsupportive of the hosting as they argued the Conference would build his reputation by co-opting women's rights into his agenda. ${ }^{26}$ It was from here that the idea of a parallel NGO event emerged (though as discussed above, such a feminist tactic was used as far back as the Paris Peace Conference in 1919).

Created by Mildred Persinger (US) and Marcia-Ximena Bravo (Ecuador), the NGO Tribune met five kilometres south of the main conference and contained many of the same delegates. ${ }^{27}$ The NGO Tribune would be an open space for wider debate amongst feminists unconstrained by the structure of UN thematic conferences and critically would not seek to speak with one voice.

\section{5 conference on women}

One commentator stressing the importance of the Mexico conference stated that "[n]ot since Adam and Eve ate the apple has this earth been faced with a social issue as complex as that which drew the delegates to the International Women's Year Conference in Mexico City." 28 Though this in its biblical referencing, and particularly mention of the human Fall, in many ways falls into the stereotypes of debates on women that would characterize much of the reportage on the event. Both the UN Conference and the parallel NGO Tribune commenced on the 23rd of June 1975. The task of the former was the promulgation of a World Plan of Action for addressing the inequalities facing women around the globe. The latter had no specific agenda and would constitute a forum for free debate. Attendance at the Conference, despite the costs, was encouraging. Notwithstanding a lack of funding and poor organization, 125 of the UN's member states sent delegations, numbering over 2000 individuals, with over 8000 people in total, almost $75 \%$ were women. ${ }^{29}$ The NGO Tribune exceeded this total-being attended by $6,000 .{ }^{30}$

Of course, the number of women delegates deserves to be commended as an impressive achievement, but it is worth recollecting that the delegates in question were under the close control of their respective governments. Fraser (US), who 
attended the conference, recollected how US delegates were strictly instructed not to hold any communication with those delegates from the socialist bloc. ${ }^{31}$ The USSR delegates and others from the socialist bloc, in turn, were likely under similar restrictions. What is more, the location of the Conference impacted upon the geographical spread of those who could attend. Being in Mexico City, attendance was dominated by US and South American members. Individuals from the continents of Africa and Asia struggled to find the resources to undertake the trip, were thus underrepresented, depriving the Conferences of an important intersectional element. The UN Conference got off to an unfortunate start, with the first two speakers being men. UN Secretary General Kurt Waldheim and President Luis Echeverría of Mexico were the first voices to be heard. Mexican Attorney General Pedro Ojeda Paullada was elected President of the Conference, a point that would become the centre of dispute between the US and Global South feminists. Even with a majority of women attending, the initial tone was male.

As the dual conferences got underway, the geopolitical tensions between the West and the USSR, and between the West and the recently decolonised states allied to the Non-Aligned Group, became manifest. ${ }^{32}$ This was alongside the frictions already developing between Western feminists and those of the Global South, especially as US feminists began having their predominance challenged. ${ }^{33}$ For these US and Western feminists, their core beliefs were in grass-root feminism, the creation of particular legal rights to achieve equality, and suspicion of what masculine dominated state-based structures could achieve in the emancipation of women. More specifically, they eschewed overtly political and economic considerations, seeking to centre debate around such issues as legal inequalities, sexual liberation, employment discrimination, education, and representation. ${ }^{34}$ The lack of focus or even identification of what would subsequently be identified by Crenshaw as intersectionality would remain a problem for Western feminist leadership. ${ }^{35}$

To the US delegates' dismay, other delegates sought to refocus attention, with contemporary commentators remarking that the "women's revolution was immediately faced by what seemed like a counterrevolution." ${ }^{36}$ Within the UN conference's plenary sessions, delegates from the Global South stressed the centrality of addressing economic concerns and the establishment of a fairer international economic system as a prerequisite to the realization of any gender equality. As Sirimave Bandaranaike, the Prime Minister of Sri Lanka, argued, the disputations of gender equality that characterize Western discourse were just not applicable to a polity that can scarcely guarantee subsistence for women.

This, predictably, was met by curt dismissals by Western delegates. France's Françoise Giroud, for one, condemned attempts to "divert the Conference from its true purpose into 'New Economic Order Problems'." 37 The reference to the New International Economic Order is significant. The Charter on Economic Rights was now adopted and significantly challenged the legal economic order dominated by the historical colonial powers and further change appeared possible (even if eventually it would not meet all its aims). ${ }^{38}$ But the right to development as a distinct legal claim was already fomenting and it is unsurprising that feminists from the Global South would see the need to insert women into that right 
as being an essential aspect of their emancipation. ${ }^{39}$ The New International Economic Order was regarded in the Global North as a threat and entirely negative prospect. The failure of the Global North feminists to see its possibilities became a key point of dispute.

The USSR, through their delegate Valentina Tereshkova, likewise rejected the ideas of equality espoused by the US feminists. To their perspective, the end of man's ability to exploit another man under the communist social model had realized equality for both men and women. While exaggerated, the achievements of the USSR and Eastern-bloc countries in achieving gender equality have been demonstrated in recent studies and within diplomacy. Indeed, communist states were amongst the first to appoint women as diplomats, including Alexandra Kollontai as one of the first senior woman diplomats in $1924 .{ }^{40}$ Ghodsee, for one, points to the clear evidence of the USSR's “significant achievements in terms of women's literacy, education, legal equality, reproductive rights, and/or incorporation into the labor force." ${ }^{41}$ For the USSR, the next step in securing equality was the integration of women's voices into those dialogues addressing questions of world peace (colonialism, neo-colonialism, nuclear proliferation). In response to this contribution, Whitaker (a contemporary commentator from the US) cursorily condemned the USSRs for abstaining "from the revolutions of both women and the poor." 42

At the NGO Tribune, the tensions between competing claims emerged most clearly. Upon the Mexican Attorney General Pedro Ojeda Paullada being elected president of the UN Conference, US activist Betty Friedan denounced it. She argued that having a man preside over a conference concerning the condition of women was an absurdity. She established a Feminist Caucus within the Tribune to contest the presidency - though it should be noted that Friedan was not representative of the entirety of US feminists nor their diverse experiences at the Conferences. ${ }^{43}$ Friedan, however, faced a significant backlash. Latin American women were in support of Paullada, a point that reflects their belief in the power of the state to effect change. Freidan's activities also raised concerns amongst delegates that the US representatives were attempting to dominate proceedings at the Tribune. ${ }^{44}$ Mexican media lambasted Friedan as a caricature for privileged liberal Western feminism, in which the sole objective was the establishment of complete equality between men and women. In this vein, the press drew particular attention to her masculine features nicknaming her "The Terrible" and "The Threat," an often repeated trope used to undermine women's authority. ${ }^{45}$

Domitila Barrios de Chungara (Bolivia) represented an important rallying point for Third World frustration with US feminists. Coming from a Bolivian tin-mining community, Domitila expected the Conference and Tribune to be a space where women from economically depressed backgrounds could combine to campaign for substantial international economic reorganization. Upon arrival in Mexico, however, she felt immediately alienated by the various panels discussing what she characterized as First World concerns: sexual liberation and the fight to achieve equality. ${ }^{46}$ The specific issues facing women from less industrialized economies and rural areas were being marginalized. Against this, Domitila, in a series of speeches, brought the question of economic advantage centre stage, highlighting the harsh conditions women like her faced. 
The tensions within the NGO Tribune came to a head regarding the absence of a representative of the Tribune at the UN Conference. Growing frustrated at the inability of the Tribune to directly impact upon the proceedings of the UN Conference, the feminist caucus - lead by Friedan — restyled themselves the "United Women of the Tribune" and began holding private meetings and organizing to have petitions delivered to the UN conference. ${ }^{47}$ While certainly a bold move, private side meetings have long been a feature of Global North proceedings at Conferences as epitomized by "Green Room" meetings at the GATT and WTO. ${ }^{48}$ Notwithstanding that, Friedan was lionized in subsequent US accounts as bravely standing up to the UN delegates and as uniting the "women of the world," but her fellow tribunal members disagreed.

While certainly attempting to appear cosmopolitan, the United Women of the Tribune quickly became associated with US feminists. Rival groups established themselves to contest the usurpation of the Tribune's voice. These included the Coalition of Latin American Women (who rejected universalism, seeking to establish a distinctly Latin American Voice) and the Women Against Imperialism (a Marxist group that included Domitila amongst its members). ${ }^{49}$ These disagreements were exploited by mainstream media commentators who emphasized the differences between the delegates following a traditional narrative of infighting feminists and emotional women which, as Olcott has pointed out, occludes much of the debate and misrepresents events. ${ }^{50}$ This depiction of the Conference and Tribune, while fairly typical of reporting of women's' activism in this period, and while the disagreements remain fundamental to feminist debates today, such disagreements at world conference is not just the purview of those that address women.

Both Conferences concluded amicably. The juxtaposed viewpoints of the East and West, and the now vocal perspectives of the Global South, remained in conflict, but divisive episodes that took place were enlarged to obscure the genuine achievement that the Conference represented. Further, Western feminists were slow to take on board the issues of intersectionality that the Conference had brought to the foreground. In a highly dismissive survey of the proceedings, Whitaker described the Global South as being so singularly intent upon wealth redistribution, that feminists had to wonder whether "the Third World position did not reflect a disdain or hostility by their countries and their male-dominated governments for the goals of the conferences." ${ }^{51}$ To be sure, she did admit of the unique economic difficulties that developing countries face and the privileged position Western feminists inhabit, (Whitaker 1975) but the tone is condescending. If anything, the recognition of the unique concerns of Third World Women merely reinforces the conviction that Western women "have led the way" in the fight for equality. ${ }^{52}$

\section{The world plan of action}

The adoption of the World Plan of Action was a tortuous process. While drafts of the World Plan had already been composed by a UN Consultative Committee based on principles of equality embodied in various Treaties, it remained a 
difficult task to gain agreement. ${ }^{53}$ During the Conference the Drafting Committee heard over a hundred speeches detailing the global lived experiences of women. 894 amendments were proposed by the Committees, the Tribune, and feminist NGOs. The volume and variety are unsurprising given the hitherto inattention to women's issues and the inaudibility of women from the Global South that had been the norm up to this point. ${ }^{54}$ In the final 24-hour sessions, the fatigued Conference demurred in debating these proposals and unanimously accepted the World Plan of Action. ${ }^{55}$

In addition to the World Plan of Action, and a testimony to the policy divides that characterized the proceedings in Mexico, the UN Conference adopted as a preamble to the Plan an additional Declaration of Mexico on the Equality of Women and Their Contribution to Development and Peace. ${ }^{56}$ The proposal was brought by the Non-Aligned Movement and represents their particular concern of realizing a more equitable economic order. It passed by 89 votes to 2, with 19 abstentions. Revealingly, the US was included in the number of States voting directly against the proposal. Nonetheless, the influences of Western feminism within the document remain evident. The Declaration stresses "that women and men of all countries should have equal rights and duties and that it is the task of all States to create the necessary conditions for the attainment and the exercise thereof;" 57 and asserts the principle that "[e]quality between women and men means equality in their dignity and worth as human beings as well as equality in their rights, opportunities and responsibilities." ${ }^{58}$

However, the combined importance of the voices from the Eastern bloc and the Global South was critical. With respect to the latter, at principle 14, the Declaration asserts that:

[t]he issue of inequality, as it affects the vast majority of women in the world, is closely linked with the problem of under-development, which exists as a result not only of unsuitable international structures but also of a profoundly unjust world economic system. ${ }^{59}$

From this postulate, article 18 declares that it is "essential to establish and implement with urgency the New International Economic Order." ${ }^{60}$ This order is said to be founded upon the basic elements of "equity, sovereign equality, interdependence, common interest, co-operation among all States irrespective of their social and economic systems and on the principles of peaceful coexistence and on the promotion by the entire international community of economic and social progress of all countries, especially developing countries. ${ }^{\prime 61}$ Finally, in article 19, the Declaration affirms "[ $\mathrm{t}]$ he principle of the full and permanent sovereignty of every State over its natural resources, wealth and all economic activities, and its inalienable right of nationalisation as an expression of this sovereignty." ${ }^{26}$ This language sits very much alongside the Charter of Economic Rights and Duties in focusing on economic sovereignty, natural resources, and nationalization but brings women's economic position to bear upon the New International Economic Order. $^{63}$ 
The USSR's insistence on women's inclusion within international affairs, a space where women remained, and still remain, absent, is set out in principle 2, where states are required to ensure women's "participation in securing and in maintaining international peace" and in principle 25 , that "[w] mem must participate equally with men in the decision-making processes which help to promote peace at all levels." ${ }^{\prime 64}$ These quite general statements are supported by the comparatively bold principle 26 , which declares that "[w]omen and men together should eliminate colonialism, neo-colonialism, imperialism, foreign domination and occupation, Zionism, apartheid, racial discrimination, the acquisition of land by force and the recognition of such acquisition." ${ }^{\prime 65}$ The inclusion of such a programme is justified on the grounds that "such practices inflict incalculable suffering on women, men and children." 66

Finally, in article 29, the ideas of sovereign equality and the right to nonintervention are reinforced:

Peace requires that women as well as men should reject any type of intervention in the domestic affairs of States, whether it be openly or covertly carried on by other States or by transnational corporations... [and] that women as well as men should promote respect for the sovereign right of a State to establish its own economic, social, and political system without undergoing political and economic pressures or coercion of any type.$^{67}$

This should be viewed alongside General Assembly Resolutions, led by the expanding number of Global South states which attempted to carve a place for the General Assembly in peace and security away from the dominance of the Permanent Five on the Security Council but also to re-assert that non-intervention was the norm. ${ }^{68}$

As to the World Action Plan itself, the document contains the concerns of the Global South and the Eastern bloc. The introduction to the plan includes references to the need for the elimination of "the last vestiges of alien and colonial domination, foreign occupation, racial discrimination, apartheid and neo-colonialism in all its forms" ${ }^{69}$ and the inequalities within development. Its stresses the point that women subsisting in regimes - such as apartheid — struggle "tirelessly for the recovery of the most elementary rights of the human person." Likewise, the need for the protection of state sovereignty is highlighted, and the "inadmissibility of acquisition or attempts to acquire territory by force, mutual advantage, the avoidance of the use or the threat of force, and the promotion and maintenance of a new just world economic order."71 That being said, the USSR and Global South voices remain quite imprecise and general. Clear provision as to how these goals are to be realized was not given concrete expression. There are suggestions that States should ensure that women "are equitably represented among the principal delegates to all international bodies, conferences and committees"72 and that the UN should focus upon the "preparation of international conventions, declarations, and formal recommendations, and the development of reporting systems." 73 Such statements, however, do not foist any clear mandate 
upon States to act. The national development goals that the Plan does set are, in contrast, much more precise and technical. For example, the plan envisages that in the next five-year period there should be achieved as a minimum:

i "Marked increase in literacy and civic education of women, especially in rural areas." 74

ii "Equal access at every level of education, compulsory primary school education and the measures necessary to prevent school drop-outs." 75

iii "Provision for parity in the exercise of civil, social and political rights such as those pertaining to marriage, citizenship and commerce." 76

iv "The establishment of interdisciplinary and multisectoral machinery within the government for accelerating the achievement of equal opportunities for women and their full integration into national life."77

None of these principles and propositions were binding. As one commentator described it, the Plan merely had "hortatory" force but after its adoption by the UN General Assembly the possibility of it morphing into soft law and becoming the basis of further legal and policy reform became extant. The Plan of Action also scheduled a further conference to be held at Copenhagen in five years' time in order to assess the progress made by States in the fulfilment of the agenda set out in Mexico City.

\section{Outcome}

Following the Conference, the General Assembly endorsed the World Plan of Action proclaiming 1976-1985 as the United Nations Decade for Women. ${ }^{78}$ This was followed by additional conferences in Copenhagen in 1980 and Nairobi in 1985, though both conferences confirmed the lack of progress that had been made since Mexico City. That said, following the Mexico Conference, an existing UN body was renamed the Branch for the Advancement of Women. This institution would progress through several evolutions and now forms part of UN Women. The United Nations Development Fund for Women, though also evolving through several forms, would also emerge from the Decade for Women. There were also significant non-UN events and Conferences that eschewed UN structures, such as the International Tribunal on Crimes against Women. ${ }^{79}$

The Beijing Conference rivals Mexico in importance and significance and while it too had controversies and disagreements the established space to specifically discuss issues facing women and the impossibility of Western feminists dominating the narrative is evident. ${ }^{80}$ It was also the last Conference of its specific type - though women activists have also utilized a series of 1990 UN sponsored Conferences to further their concerns. ${ }^{81}$ Despite the fact that there remains an overarching concern as to whether these forms of conferences are the best avenue to affect legal and political change, ${ }^{82}$ the Mexico Conference and the subsequent events in Copenhagen 1980, Nairobi 1985 and Beijing 1995 provided spaces for women to meet, to build alliances, and to learn from each other including about strategies and failures in campaigning. ${ }^{83}$ 


\section{Conclusion}

Differing perspectives on how to support women, what to forefront, what to fund, what to set into law, what to leave to policy, are fundamental to considering how to finally achieve full substantive equality for women. The 1975 Conference succeeded in forefronting that complexity and what was reported as an argumentative space was actually the first proper opportunity for women of the Global South to articulate their priorities within the formalised UN space. It would now be inconceivable that women of the Global North would dominate agendas and podiums, and while there is still a very long road ahead for Western feminism to finally cede space and end attempts to represent all women Mexico represented a first break in that (misguided) attempt to speak for all women.

The Mexico City Conference also demonstrated the complexity of women's lives and that the East-West divisions were not the only ones of consequence. The New International Economic Order in particular drew attention to the postcolonial realities of many women's lives, and while women in the Global South maintain their campaigns to be heard, to be participants, to set agenda, and to write policy and law, Mexico City ruptured a settled description of women's issues at the international level. Issues of sexuality, indigenous women's rights, and bodily autonomy or of simply being recognized as a valid voice at the table remain. Even within the UN secretariat, women's equality remains an outstanding goal. The UN and NGO level are also not the sole avenues of activism and change. Mexico City in 1975 was a critical moment where women infiltrated and created their own agendas and set-in motion a (slow) process of change. The UN did not create, nor has it supported, feminism to any great extent, and UN activities "are not substitutes for women's movements nor should they be expected to be so" or indeed advocated as such. ${ }^{84}$ Such events are also, without funding and support, inaccessible to those women who face the hardest challenges. Nonetheless they have shone light on women's issues and built alliances and assisted in changes in policy, law, and most importantly lives and these should not be discounted.

\section{Notes}

1 Jean H. Quataert, Benita Roth 'Human Rights, Global Conferences, and the Making of Postwar Transnational Feminisms' (2012) Journal of Women's History 11, 15.

2 For an overview of media strategies and depictions of women in the media in this context see Jocelyn Olcott 'Empires of Information: Media Strategies for the 1975 International Women's Year' (2012) 24 Journal of Women's History 24.

3 See Marino 'From Women's Rights to Human Rights', this volume, ch.1.

4 Helen McCarthy, Women of the World: The Rise of the Female Diplomat (Bloomsbury, 2014).

5 Jill Liddington, The Road to Greenham Common: Feminism and Anti-militarism in Britain Since 1820 (Syracuse University Press, 1989).

6 Constitution of the International Labour Organisation Constitution under Article 9.3 on staff that '[a] certain number of these persons shall be women' and under Article 3.2 on Meetings and Delegates that, ' 2 . Each delegate may be accompanied by advisers, who shall not exceed two in number for each item on the agenda of the meeting. When questions specially affecting women are to be considered by the Conference, one at least of the advisers should be a woman.' 
7 Margaret E Galey, 'Forerunners in Womens Quest for Partnership' in Anne Winslow (ed), Women, Politics, and the United Nations (Greenwood Publishing Group, 1995) 5.

8 Margaret E Galey, 'Forerunners in Womens Quest for Partnership' in Anne Winslow (ed), Women, Politics, and the United Nations (Greenwood Publishing Group, 1995) 5.

9 Sandi E Cooper, 'Peace as a Human Right, The Invasion of Women into the World of High International Politics' (2002) 14 Journal of Women's History 9, 12.

10 Hilkka Pietilä, The Unfinished Story of Women and the United Nations (NGLS development dossier, 2009) 7-8.

11 ibid 9-10.

12 Jean H. Quataert, Benita Roth 'Human Rights, Global Conferences, and the Making of Postwar Transnational Feminisms' (2012) Journal of Women's History 11, 16.

13 Gayatri Spivak 'Can the Subaltern Speak?' in Rosalind C Morris (Ed) Can the Subaltern Speak?: Reflections on the History of an Idea (Columbia University Press, 2010) 33.

14 Introduction' in L Eslava, M. Fakhri, V. Nesiah (eds.) Bandung, Global History, and International Law Critical Pasts and Pending Futures (CUP, 2017) 17.

15 Jocelyn Olcot, International Women's Year: The Greatest Consciousness-Raising Event in History (OUP, 2017) 19.

16 United Nations International Years https://www.un.org/en/sections/observances/international-years/index.html

17 Commission on the Status of Women: Report on the Twenty-Fourth Session UN doc. E/CN.6/L.644, 29 February 1972, 157, 185.

18 The inclusion of development and peace followed sustained wrangling regarding extending the purview of what was a women's' issue beyond the traditional boundary of liberal rights. See: United Nations General Assembly Resolution 3010 (XXVII) A/ RES/27/3010 (XXVII) 18 December 1972.

19 Olcott (n 14) 23.

20 ibid $27-33$.

21 CSW, 25th session, 15 January 1974, UN doc. E/CN.6/L.658.

22 CSW, 25th session, 21 January 1974, UN doc. E/CN.6/L.659. Olcott (n 2) 44.

23 General Assembly Resolution A/RES/3277(XXIX) Consultative Committee for the Conference of the International Women's Year $10^{\text {th }}$ December 1974.

24 Olcott (n 14) 42.

25 General Assembly Resolution A/RES/3281(XXIX) Charter of Economic Rights and Duties of States UN doc. E/L.1615, 18 November 1974.

26 Olcott (n 14) 58.

27 There was also an East Berlin Conference.

28 Jenifer Whitaker, 'Women of the World: Report from Mexico City' (1975) 54(1) Foreign Affairs 173.

29 Kristen Ghodsee, 'Revisiting the United Nations Decade for Women: Brief Reflections on Feminism, Capitalism and Cold War Politics in the Early Years of the International Women's Movement' (2010) 33 Women's Studies International Forum 244, Charlotte Bunch 'Opening Doors for Feminism: UN World Conferences on Women' (2012) Journal of Women's History 213, 214.

30 ibid.

31 Whitaker (n 28).

32 Quataert, Roth (n 11) 11-12.

33 Western feminists had already been anticipating such an eventuality. See https://www. nytimes.com/1975/06/19/archives/international-womens-year-world-conferenceopening-in-mexico.html

34 Judith P Zinsser, 'From Mexico to Copenhagen to Nairobi: The United Nations Decade for Women, 1975-1985' (2002)) Journal of World History 139, 140.

35 Kimberlé Crenshaw, 'Mapping the Margins: Intersectionality, Identity Politics and Violence Against Women,' in Kimberlé Crenshaw, Neil Gotanda, Gary Peller, and 
Kendall Thomas (eds), Critical Race Theory: The Key Writings that Formed the Movement, ed. (The New Press, 1995) 357.

36 Whitaker (n 28) 173.

37 Marguerite Rawalt, 'UN World Conference in International Women's Year and Tribune - Mexico City' (1975) 61 Women's Law Journal 184, 186.

38 S Chatterjee, 'The Charter of Economic Rights and Duties of States and the New International Economic Order' (1991) 40 ICLQ 669.

39 S Chowdhury, E M.G. Denters, P.J.I.M. de Waart, 'The Right to Development in International Law' (Martinus Nijhoff Publishers, 1992).

40 Diana Apcar of Armenia is recognised as the first in 1920.

41 Ghodsee (n 29) 247.

42 Whitaker (n 28) 173.

For an account of the marginilisation of non-western voices to the development of feminism, see Kristen Ghodsee 'Research Note: The Historiographical Challenges of Exploring Second World-Third World Alliances in International Women's Movement' (2014) 14(2) Global Social Policy 244.

43 Olcott (n 14) 115, Charlotte Bunch 'Opening Doors for Feminism: UN World Conferences on Women' (2012) Journal of Women’s History 213, 213.

44 ibid 120-121.

45 ibid 126.

46 ibid 140-142.

47 ibid 169.

48 Kent Jones, 'Green room politics and the WTO's crisis of representation' (2009) 9 Progress in Development Studies 349.

49 Olcott (n 14) 171.

50 Olcott (n 2) 2.

51 Olcott (n 14) 187.

52 ibid 180.

53 Though not all had sufficient ratifications to be legally binding Hermina Strauss, 'The Legal Issues Facing International Women's Year Conference in Mexico City on June 19, 1975' (1975) 61(2) Women Lawyers Journal 66.

54 Gayatri Spivak 'Can the Subaltern Speak?' in Rosalind C Morris (ed), Can the Subaltern Speak?: Reflections on the History of an Idea (Columbia University Press, 2010) 33.

55 UN General Assembly, Implementation of the World Plan of Action adopted by the world Conference of the International Women's Year, 12 December 1975, A/ $\mathrm{RES} / 3490$.

56 UN General Assembly, Implementation of the World Plan of Action adopted by the world Conference of the International Women's Year, 12 December 1975, A/ RES/3490.

57 Declaration 3. https://www.un.org/womenwatch/daw/beijing/otherconferences/ Mexico/Mexico\%20conference\%20report\%20optimized.pdf

58 ibid 4.

59 ibid 5.

60 ibid.

61 ibid.

62 ibid 6.

63 General Assembly Resolution A/RES/3281(XXIX) Charter of Economic Rights and Duties of States UN doc. E/L.1615, 18 November 1974.

64 UN General Assembly, Implementation of the World Plan of Action adopted by the world Conference of the International Women's Year, 12 December 1975, A/ RES/3490, 6.

65 Ibid.

66 ibid 7.

67 ibid. 
68 UN General Assembly, Uniting for peace, 3 November 1950, A/RES/377.

69 UN General Assembly, Implementation of the World Plan of Action adopted by the world Conference of the International Women's Year, 12 December 1975, A/ RES/3490.

https://www.un.org/womenwatch/daw/beijing/otherconferences/Mexico/Mexico\%20 conference $\% 20$ report $\% 20$ optimized.pdf 9.

70 ibid 11.

71 ibid 12.

72 ibid 36.

73 ibid.

74 ibid 16.

75 ibid.

76 ibid.

77 ibid 17.

78 UN General Assembly Resolution 3520 World Conference of the International Women's Year, Hanna Papanek, 'The Work of Women: Postscript from Mexico City' 19751 Signs 215.

79 Diana E. H. Russell, Nicole Van de Ven Crimes against Women: Proceedings of the International Tribunal (Les Femmes Pub., 1976).

80 https://www.unwomen.org/-/media/headquarters/attachments/sections/csw/pfa_e_ final_web.pdf?la=en\&vs=1203

81 Marilyn Porter, 'Transnational Feminisms in a Globalized World: Challenges, Analysis, and Resistance' (2007) 33 Feminist Studies 43.

82 Hilary Charlesworth, 'Women as Sherpas: Are Global Summits Useful for Women?' (1996) 22 Feminist Studies 537.

83 Charlotte Bunch 'Opening Doors for Feminism: UN World Conferences on Women' (2012) Journal of Women's History 213, 213.

84 ibid 213.

\section{Bibliography}

Bunch, Charlotte. "Opening doors for feminism: UN world conferences on women." Journal of Women's History 24, no. 4 (2012): 213-221.

Chatterjee, S. K. "The charter of economic rights and duties of states: An evaluation after 15 years." The International and Comparative Law Quarterly 40, no. 3 (1991): 669-684.

Charlesworth, Hilary. "Women as Sherpas: Are global summits useful for women?" Feminist Studies 22, no. 3 (1996): 537-547.

Chowdhury, Subrata Roy, Erik MG Denters, and Paul JIM de Waart, eds. The Right to Development in International Law. Leiden: Martinus Nijhoff Publishers, 1992.

Cooper, Sandi E. "Peace as a human right: The invasion of women into the world of high international politics." Journal of Women's History 14, no. 2 (2002): 9-25.

Crenshaw, Kimberle. "Mapping the margins: Intersectionality, identity politics, and violence against women of color." Stan. L. Rev. 43 (1990): 1241.

Eslava, Luis, Michael Fakhri, and Vasuki Nesiah, eds. Bandung, Global History, and International Law: Critical Pasts and Pending Futures. Cambridge, New York: Cambridge University Press, 2017.

Galey, Margaret E. "Forerunners in women's quest for partnership Contributions." Women's Studies 151 (1995): 1-10.

Ghodsee, Kristen. "Revisiting the United Nations decade for women: Brief reflections on feminism, capitalism and Cold War politics in the early years of the international women's movement." Women's Studies International Forum, 33, no. 1 (2010): 3-12. 
Jones, Kent. "Green room politics and the WTO's crisis of representation." Progress in Development Studies 9, no. 4 (2009): 349-357.

Liddington, Jill. The Road to Greenham Common: Feminism and Anti-Militarism in Britain Since 1820. Syracuse, N.Y: Syracuse University Press, 1991.

McCarthy, Helen. Women of the World: The Rise of the Female Diplomat. London: A \& C Black, Bloomsbury Publishing, 2014.

Olcott, Jocelyn. "Empires of information: Media strategies for the 1975 international women's year." Journal of Women's History 24, no. 4 (2012): 24-48.

Olcott, Jocelyn. International Women's Year: The Greatest Consciousness-Raising Event in History. United States: Oxford University Press, 2017.

O'Donoghue, A. 'Article 7 of the Covenant of the League of Nations, 1919' in E Rackley and R Auchmuty Women's Legal Landmarks. Bloomsbury, 2018.

Papanek, Hanna. "The work of women: Postscript from Mexico City." Signs: Journal of Women in Culture and Society 1, no. 1 (1975): 215-226.

Pietilä, Hilkka, and Beth Peoch. The Unfinished Story of Women and the United Nations. United Nations Non-Governmental Liaison Service, 2007.

Porter, Marilyn. "Transnational feminisms in a globalized world: Challenges, analysis, and resistance." Feminist Studies, (2007): 43-63.

Quataert, Jean H., and Benita Roth. "Guest editorial note: Human rights, global conferences, and the making of postwar transnational feminisms." Journal of Women's History 24, no. 4 (2012): 11-23.

Rawalt, Marguerite. "UN world conference in international women's year and tribune-Mexico City, June 19-July 2, 1975.” Women Law Journal 61 (1975): 184.

Russell, Diana EH, and Nicole Van de Ven, eds. Crimes Against Women: Proceedings of the International Tribunal. Frog in the Well, 1976.

Spivak, Gayatri 'Can the subaltern speak?' in Rosalind Morris, ed. Can the Subaltern Speak?: Reflections on the History of an Idea. Columbia University Press, 2010.

Strauss, Hermina. "The Legal Issues Facing International Women's Year Conference in Mexico City on June 19, 1975.” Women Law Journal 61 (1975): 66.

Whitaker, Jennifer Seymour. "Women of the world: Report from Mexico City." Foreign Affairs 54 (1975): 173.

Zinsser, Judith P. "From Mexico to copenhagen to nairobi: The United Nations decade for women, 1975-1985." Journal of World History (2002): 139-168. 